\title{
Rejoinder to Passé-Smith
}

\section{Byron W. Daynes, Brigham Young University \\ Glen Sussman, Old Dominion University}

We appreciate the careful reading that Professor John Passé-Smith has given our article, and generally value his perspectives. Moreover, after a thorough reading of his criticisms, we have concluded that our respective understandings of fast tracking may not be as far removed from one another as first might appear. All three of us, for instance, could probably agree that: (1) the two institutions (President and Congress) brought together by fast tracking share different perspectives on trade policy, as most clearly exhibited in the 1930s with the Smoot-Hawley Tariff Act (Schattschneider 1935); (2) fast tracking encourages a distinct relationship between these institutions, dissimilar from treaty making and the executive agreement; and (3) we need to examine some empirical evidence supporting our assertion that fast tracking makes it difficult for members of Congress to represent and speak for their constituents on trade matters. To be sure, each of the following peculiar characteristics of fast tracking that would interfere with a Congressperson representing his/her constituents easily can be tested: (a) limited time for debate, (b) no chance to amend, and (c) the "up" and "down" vote. In addition, we offer an examination of the 1991 roll call data on fast tracking indicating that members in some regions of the country had particular difficulty in supporting fast tracking. The most susceptible regions we found were in the Rust Belt areas of the country where one sees high levels of blue-collar workers, where manufacturing jobs predominate, and where there is the greatest chance of loss of jobs to foreign countries. Here we expected that legislators might be most likely to feel that fast tracking constrained their ability to speak for their constituents and, consequently, would be most opposed to it. 'Indeed, we did find that members representing Rust Belt regions were more likely than non-Rust Belt colleagues to oppose the extension of presidential fast tracking authority as represented by H.R. 101 (a measure that would have dispensed with fast tracking for two years), and were more opposed than members of other regions to H.R. 146

Byron W. Daynes is Professor of Political Science at Brigham Young University.

Glen Sussman is Assistant Professor of Political Science at Old Dominion University. 
(a measure concerning the adoption of a two-year extension of fast tracking authority). Similarly, Rust Belt senators were more supportive of S.R. 78 (a Senate resolution disapproving fast tracking, similar to H.R. 101). Thus, those Congresspersons most in need to voice their concerns about loss of jobs in their particular constituencies showed the most opposition to fast tracking. ${ }^{2}$

\section{Table 1. Level of Support for the Fast Track Among Members of the House and Senate, by Region}

\begin{tabular}{|c|c|c|}
\hline & $\begin{array}{l}\text { Rust Belt } \\
(\%)\end{array}$ & $\begin{array}{c}\text { Non-Rust Belt } \\
(\%)\end{array}$ \\
\hline \multicolumn{3}{|l|}{$H 101$} \\
\hline Disapproval of the Fast Track Measure & 62 & 43 \\
\hline \multicolumn{3}{|l|}{$H 146$} \\
\hline Adopt Two Year Extension & 67 & 85 \\
\hline \multicolumn{3}{|l|}{$S 78$} \\
\hline Disapproval of the Fast Track Measure & 59 & 52 \\
\hline \multicolumn{3}{|c|}{$\begin{array}{l}\text { NOTE: The percentage represents the average level of support for the legislative measures } \\
\text { determined by each state delegation's vote aggregated by region (Rust Belt v. Non-Rust } \\
\text { Belt). }\end{array}$} \\
\hline
\end{tabular}

While the president has an upper hand in trade policy under fast tracking, this does not suggest, as Passé-Smith alleges that we assert, that it is a "zero sum game.". All we avow is that under fast tracking, the president gains more from the interaction than does the Congress. The hand of the President is strengthened in trade matters at the expense of Congress, but this does not suggest that Congress cannot exert influence over the resulting policy. One way, in fact, for Congress to affect trade policy under the fast track is through the strong trade committees-the House Ways and Means Committee and the Senate Finance Committee-but as we point out, Congress' input here is restricted primarily to those who sit on the committees, and even their influence is limited to a specific time-frame for debate. Yet the committee members' influence far surpasses the rank-andfile members' input since the rank-and-file member is limited to debate on 
the floor and the final vote UP or DOWN, without a chance to modify the Committee's endorsement of the agreement. For the regular member, the fast tracking process is, in the words of Representative David Bonior (D-MI), a process that ". . eats away at what we do, it is just a usurpation of our ability ... it also takes away the ability of the House to independently change things" (Bonior 1993). Fast tracking creates a gap, much wider than in other policy areas, between the committee members and the rank-and-file-a point not recognized by Passé-Smith.

The most important way that Congress can have input into the process under fast tracking was shown in the recent passage of the North American Free Trade Agreement (NAFTA), which unquestionably illustrated that Congress' primary importance came through the need to solicit its vote for passage. All of the activity surrounding NAFTA that Passé-Smith alludes to in his criticism-i.e., the more than 200 New York Times articles that he meticulously counts for us, the flurry of efforts directed by the President and targeting undecided individual Congresspersons, the deals and counter-deals resulting in the "unmanaged conflict" that we called "NAFTA"-came about because of the President's need to win passage of NAFTA. Was this hecticpaced policy chaos an example of what Passé-Smith refers to as Congress "clearly helping to mold the final agreement" under fast tracking?

We suppose that it is fair to say that without fast tracking, the sort of political conflict and exchange associated with the passage of NAFTA would have been more contained within the Congress: exchanges and negotiations between the parties, among Congresspersons in various states and regions of the country, between supporters and opponents, and it would have happened in a "managed" arena. The result probably would have been an amended and altered agreement brought about by some sort of consensus or compromise and then submitted to the President for passage or rejection. Had it been by treaty, support to garner the required two-thirds vote in the Senate likely would have been managed by party leaders.

In examining these two approaches to the policy process, they seem distinct. Yet Passé-Smith sees no difference between the President "buying" the votes of the Congresspersons he needs to win, and Congresspersons "trading" these votes for passage among themselves; as he suggests, referring to these "pork" exchanges, ". . . one trough is as good as the next." We see no difference, either, except for this very important one: when the President is buying the votes, he/she (or his/her trade representative or legislative liaison) is exerting an important controlling hand over trade matters-a feat difficult for a typical Congressperson to match because of the (non)comparable resources controlled by each. To say this also suggests the secondary position Congress finds itself in under fast tracking. 
We also found it interesting that Professor Passé-Smith should quote House Majority Leader Richard Gephardt (D-MO) to the effect that if changes were to be forced on the Mexican free-trade agreement after it had been negotiated [by the President], it would have to be done in one of two ways: (a) do away with fast tracking; or (b) make changes in the implementing legislation (Bradsher 1991, D2). Here Gephardt admits that he cannot change the trade policy once negotiated by the president under fast tracking, without either doing away with the fast track mechanism, or controlling the supplementary legislation, if needed. Here again, it can be seen that the President undeniably has the upper hand under fast tracking, just as Professor Passé-Smith suggests when he states, as a "final reason for fast-track authority," that it "assure[s] the government of a country that the agreement that they negotiate with USTR negotiators will not be rewritten by Congress" [our emphasis] (Passé-Smith 1994).

Let us finally suggest that, as Passé-Smith suggests, in this age of global trade we may need a more efficient alternative to negotiate with other nations. However, to borrow a chant echoed by anti-NAFTA demonstrators, let it not be "this NAFTA!" We would suggest some kind of "fast track;" but not this fast track. There must be some process that would allow the president a freer hand in trade so that the mistakes of Smoot-Hawley are not repeated, but would be less costly than the present fast track. As a beginning step let us consider the wise counsel of Democratic House Whip (and antiNAFTA leader) David Bonior (D-MI), who described for us how other members look at trade:

On trade, there is a more global thought process with the general membership. They understand the necessity of not having each and every trade deal exposed to the amendment process ... it certainly makes sense, but they give up a tremendous amount. You could have written fast track in different ways . . . writing it the way we did, clear UP or DOWN, it . . . just really takes away our ability to deal at all. We could have written it where you were allowed certain amendments, one amendment, two amendments. amendments that dealt with either sovereignty or remedies. I mean. you could have devised something . . . I think that that thought process needs to be explored a little bit more ... some people ought to, in our opinion, devise other ways, develop a different type of fast track that isn't so fast, maybe it is a slower model (Bonior 1993).

We certainly agree that the added complexity of trade and trade negotiations demands a flexible and stable relationship between the President and Congress, but not one that enhances one institution so much to the detriment of the other. 


\section{NOTES}

1 "Rust Belt" states include those in the New England region (ME, NH, VT, MA, RI, \& CT), the Middle Atlantic region (NY, NJ. \& PA), and East North Central region (OH, IN, IL. MI, \& WI). This regional breakdown was based upon the U.S. Bureau of the Census classification of regions in the United States.

${ }^{2}$ This Table and examination of the roll calls is based upon a previous convention paper. See Glen Sussman and Byron W. Daynes, "To Delegate or Not to Delegate: Congressional Support for Presidential Fast Track Authority," paper presented at the 1993 annual meeting of the Southern Political Science Association, Savannah. GA.

\section{REFERENCES}

Bonior, David E. 15 December 1993. Interview (tape recorded), H107 Capitol, Washington, DC.

Bradsher, Keith. 1991. Gephardt Backs Efforts on Trade with Mexico. New York Times 10 May: D2.

Passé-Smith, John. 1994. Comment: Trade Politics-A Debate. American Review of Politics 15: 89-97.

Schattschneider, E.E. 1935. Politics, Pressures and the Tariff: A Study of Free Private Enterprise in Pressure Politics, as Shown in the 1929-1930 Revision of the Tariff. New York: PrenticeHall. 